\title{
EFFECT OF PRE-MILKING ANTISEPTIC TREATMENT ON THE BACTERIAL CONTAMINATION OF COW TEATS' SKIN
}

\author{
R. MIŠEIKIENE $\dot{E}^{1}$, J. RUDEJEVIENE ${ }^{2}$ \& G. GERULIS ${ }^{3}$ \\ ${ }^{1}$ Department of Animal Husbandry, ${ }^{2}$ Department of Noninfectious Disease, \\ ${ }^{3}$ Department of Food Safety and Quality; Veterinary Academy, Lithuanian \\ University of Health Sciences, Kaunas, Lithuania
}

\section{Summary}

Mišeikienė, R., J. Rudejevienė \& G. Gerulis, 2015. Effect of pre-milking antiseptic treatment on the bacterial contamination of cow teats' skin. Bulg. J. Vet. Med., 18, No 2, 159-166.

The primary objective of premilking udder preparation and teats antiseptic is to achieve an acceptable level of decontamination of teat skin. This aids in reducing the spread of microorganisms and incidence of new intramammary infections, and in minimising the number of bacteria. The aim of our studies was to investigate the influence of pre-milking teat antiseptic solutions on total bacterial contamination of teat skin. Three udder antiseptics were applied: Dermisan $0.5 \%$ (active ingredient aminopropyl laurylamine), $0.2 \%$ solution with active ingredient iodine, and foaming solution of natural compounds (lactic acid+glycerol+allantoin). Cow teats were swabbed before and after application of udder preparations. The total bacterial contamination on cows teat skin was determined employing serial dilutions and plate count method. Microorganisms were identified under uniform conditions on McConkey (for Gram-negative bacteria), Columbia blood agar medium (for staphylococci), containing 5\% sheep's blood, Edwards (for streptococci) agars. The statistical analysis of the data was performed using descriptive statistics and independent-sample $\mathrm{T}$ test procedures in SPSS 13.0 for Windows. The udder applications with lactic acid and iodine had the highest probability $(\mathrm{P}<0.05)$ of reducing total bacterial contamination. The use of udder antiseptics for premilking teats preparation reduced the levels of coliforms, coagulase negative staphylococci and Streptococcus uberis but with exception of iodine, no effect was found on reducing Candida genus yeasts.

Key words: cow, microorganisms teat antiseptic, total bacterial contamination

\section{INTRODUCTION}

Milk and dairy products quality starts on the farm with the milk producer. One of the most important issues is the control of bacteria. Bacteria in raw milk comes from two main sources: organisms transported from the environment into the milking machine and mastitis organisms from within the udder (Taverna et al., 2001; Kelly et al., 2009). Teat skin is a potential reservoir of microbial diversity for milk (Monsallier et al., 2012). Consequently, up to $1 \times 10^{10}$ of total amount of microor- 
ganisms can be found in one gramme of impurities on the surface of udder. Inadequate hygiene conditions increase the risk of penetration of microorganisms present on the udder from the tip of teats into the teat canal which could result in mammary gland inflammation (Pavičic et al., 2003). Premilking udder hygiene includes many factors, such as dryness and cleanliness of teats and udder, type of drying towel used, type and concentration of premilking sanitiser or antiseptic, and sanitiser contact time with teats (Galton et al., 1986; 1988; Nakano et al., 1995). Premilking teat preparation not only reduces environmental bacteria on the teat surface but also reduces bacteria counts in milk (Ruegg, 2003). The primary objective of premilking udder preparation and teats antiseptic is to achieve an acceptable level of decontamination of teat skin. This aids in reducing the spread of microorganisms and incidence of new intramammary infections, and in minimising the number of bacteria that find their way into the raw milk supply (Nickerson, 2001). According to El Behiry et al. (2012) bacteria of the genus Staphylococcus are one of the most common pathogens that cause mastitis worldwide. Vacheyrou et al. (2011) described the microbial community naturally present on dairy cow teat skin in link with milk and other microbial farm communities. Other researchers also confirmed that water and animal environment, teat skin (Vacheyrou et al., 2011) and udder skin can be sources of milk inoculation.

Teat skin, even on teats that look reasonably clean, may harbour a large number of coliforms, streptococci, and other bacterial species commonly found in manure and soil. It may also include $S$. aureus and other species of staphylococci and streptococci associated with cracked or injured skin. All of these potentially can cause mastitis if they enter the gland. Therefore, minimising their numbers on teat skin prior to attaching the cluster is necessary for mastitis control as well as milk quality. Pre-dipping with effective products helps accomplish this (Gleeson et al., 2009). Gibson et al. (2008) showed that a pre-milking teat cleaning regime involving the washing of teats with an effective antiseptic and then drying was the most effective for removing bacteria and minimising bacterial growth.

Studies (Ingawa et al., 1992; Ruegg et al., 2003) demonstrated that it is necessary to include disinfection with highly effective agents that are active in low concentrations and do not pose a threat regarding chemical residues in the milk. Good antiseptic material must affect immediately and in wide range, and should not leave inhibitory substances in milk (Malinowski, 2004). Efficiency of antiseptic materials depends on cleanness of washed surfaces, the microbial species, concentration and temperature of solution, exposition time and other factors.

Many producers dip teats before milking with various disinfectant products such as iodophor solution, iodine based gel, sodium hypochlorite, chlorine, chlorhexidine, lactic acid (Galton et al., 1986; Ingawa et al., 1992; Oliver et al., 1993; Gibson et al., 2008). A number of organic acids (including lactic acid) with bactericidal properties are applied as disinfectants for animal health purposes. Lactic acid may be combined with hydrogen peroxide, and this combination improves teat skin condition and minimises bacterial colonisation on the teat skin surface. Iodine is a broad-spectrum fast acting germicide that is effective against essentially all mastitis-causing bacteria. Iodine has bactericidal activity against both Grampositive and Gram-negative bacteria 
(Gleeson et al., 2009). It is shown that the use of disinfectants with iodine can have beneficial effects on reducing the levels of staphylococcal and streptococcal pathogens on teat skin (Gibson et al., 2008). The study concluded that most premilking teat cleaning treatments reduce the teat total bacterial count, but that cleaning effectiveness was influenced by the type of disinfectant and the application methods. The use of a $0.2 \%$ iodine solution before milking was also shown to reduce major pathogen intramammary infections resulting from Streptococcus uberis and Str. dysgalactiae by as much as 49\% (Oliver et al., 1993).

The aim of our studies was to determine the microbial contamination of teat skin and to evaluate the effect of investigated antiseptics on microbial counts.

\section{MATERIALS AND METHODS}

The experiment was performed during indoor period at a farm where a herd of 220 cows was held. The cows were held loose on the latticed floors and were milked at the herringbone milking parlour.

Twenty-one cows of third lactation which were free from clinical mastitis infection (no swelling, no heat, no pain, no redness of the udder; milk of normal colour, without fibrin clots) were randomly chosen to apply the udder preparation before milking. Cows were divided into 3 groups of 7 cows in each. Each group was treated with a different premilking teat antiseptic. Three antiseptics were used in the following concentrations: $0.5 \%$ Dermisan (active ingredient aminopropyl laurylamine, CAS name 2372-82-9) manufactured by Hypred (France), 0.2\% solution with active ingredient iodine, and a foaming solution of natural compounds (lactic acid+glycerol+ allantoin). Foaming solution with natural compounds for teats preparation prior milking is used daily on farms. The two other disinfectants are commercial and certified in Lithuania but were not usually used at this farm.

The teats of cows from the first treatment group were cleaned with solution containing $0.5 \%$ aminopropyl laurylamine, from the second treatment group with $0.2 \%$ iodine and the third group - with foaming solution of natural compounds accordingly. Investigations continued for 10 days. The samples were obtained prior evening milking. In all 21 cows a total of 210 samples were obtained before treatment and another 210 - after treatment (3 groups $\times 7$ cows $\times 10$ visits).

The sampling from teats before using the antiseptic was performed by triple rotary motions around the surface of the teat close to the tip from the front teat only and then the samples were placed into disposable transport Transwab ${ }^{\circledR}$ Amies (England). Exposure time of antiseptics on teats was $20 \mathrm{~s}$. Then, the teats of individual cows were dried with individual paper towel. After drying, the sampling from teats was performed again. Sterile gloves were used throughout the sampling. All samples were then transported from farm to laboratory under low temperature conditions.

The total bacterial contamination of cow teat skin was determined employing serial dilutions and the plate count method proposed by Tortora (2002). The number of colony forming units (CFU) was calculated per $1 \mathrm{~mL}(\mathrm{CFU} / \mathrm{mL})$. The $\mathrm{CFU} / \mathrm{mL}$ were determined for each individual sample (a total number 420). Under aseptic conditions, the teat samples were agitated for $10 \mathrm{~s}$ to extract the bacteria from the swab. Then, $1 \mathrm{~mL}$ of the solution was taken to produce dilutions down to $10^{3}$, 
and $0.2 \mathrm{~mL}$ of the sample was taken for spreading upon the bacteria-specific agar plates.

To identify microorganisms, samples were inoculated under uniform conditions on McConkey agar (Oxoid, England) for coliforms (E. coli, Enterobacter aerogenes, Columbia blood agar medium (Oxoid, England) for staphylococci containing 5\% sheep blood, Edwards agar (Oxoid, England) for streptococci. The samples were incubated for $24-48 \mathrm{~h}$ at $37{ }^{\circ} \mathrm{C}$ under aerobic conditions. Every $24 \mathrm{~h}$ the grown colony's size and colour were evaluated. Grown colonies were tested with $3 \%$ hydrogen peroxide solution. To identify $S$. aureus the latex kit, Staphytect Plus Test DR 850 (Oxoid, England) was used. Detailed identification of bacteria was peformed using API test (Oxoid, England) and Entero pluri Test (Liofilchem, Italy). Sabouraud medium plates (Oxoid, England) for yeast and fungi were incubated for 5 days at $25{ }^{\circ} \mathrm{C}$.

The statistical analysis of the data was performed using descriptive statistics and independent-sample $\mathrm{T}$ test procedures in
SPSS 13.0 for Windows. The difference was considered to be statistically significant when $\mathrm{P}<0.05$.

\section{RESULTS}

During our experiments, we investigated the change in the microbial on cows teats skin after treatment with different antiseptic solutions.

Summary of results for the total number of microorganisms on cows' teats skin before and after antiseptic treatments is shown on Fig. 1. There was a reduction of microbial counts on teats skin after. The number of colonies on the teats skin decreased significantly (from $50.8 \pm 21.6 \times 10^{3}$ $\mathrm{CFU} / \mathrm{mL}$ to $15.2 \pm 11.2 \times 10^{3} \mathrm{CFU} / \mathrm{mL}$, or about 3.5 times $(\mathrm{P}<0.01)$ when foaming solution of natural compounds (lactic acid+glycerol+allantoin) was used. The antiseptic solution containing $0.2 \%$ iodine decreased the number of microorganisms almost twice $\left(1.86 \times 10^{3} \mathrm{CFU} / \mathrm{mL} ; \mathrm{P}<0.05\right)$. The application of $0.5 \%$ aminopropyl laurylamine had a slightly lowering effect on teat microflora: the total bacterial con-

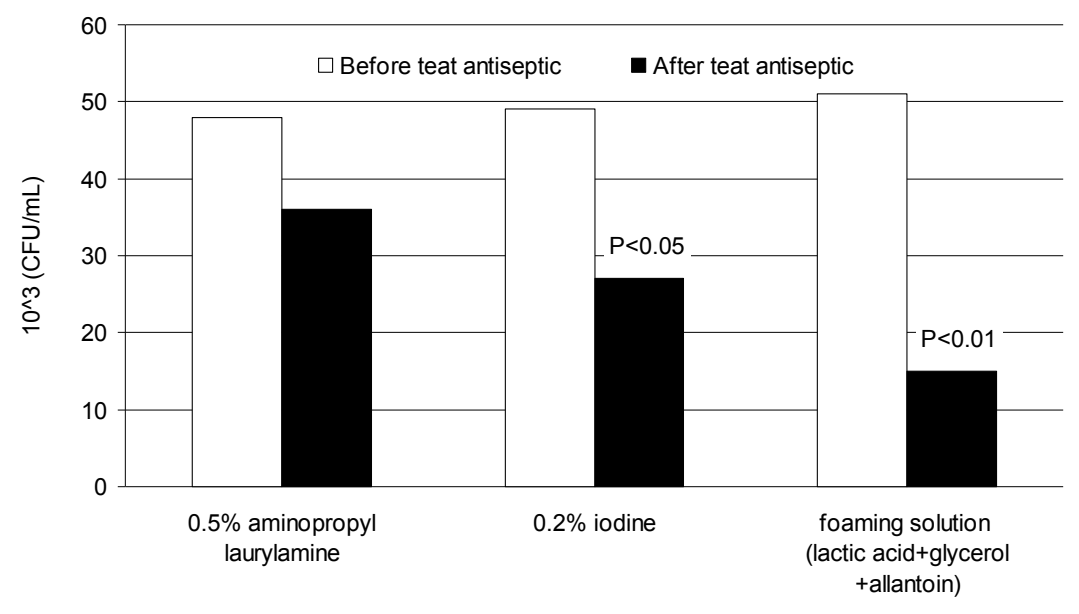

Fig. 1. Microbial colony counts on the teats before and after application of teat antiseptics. 


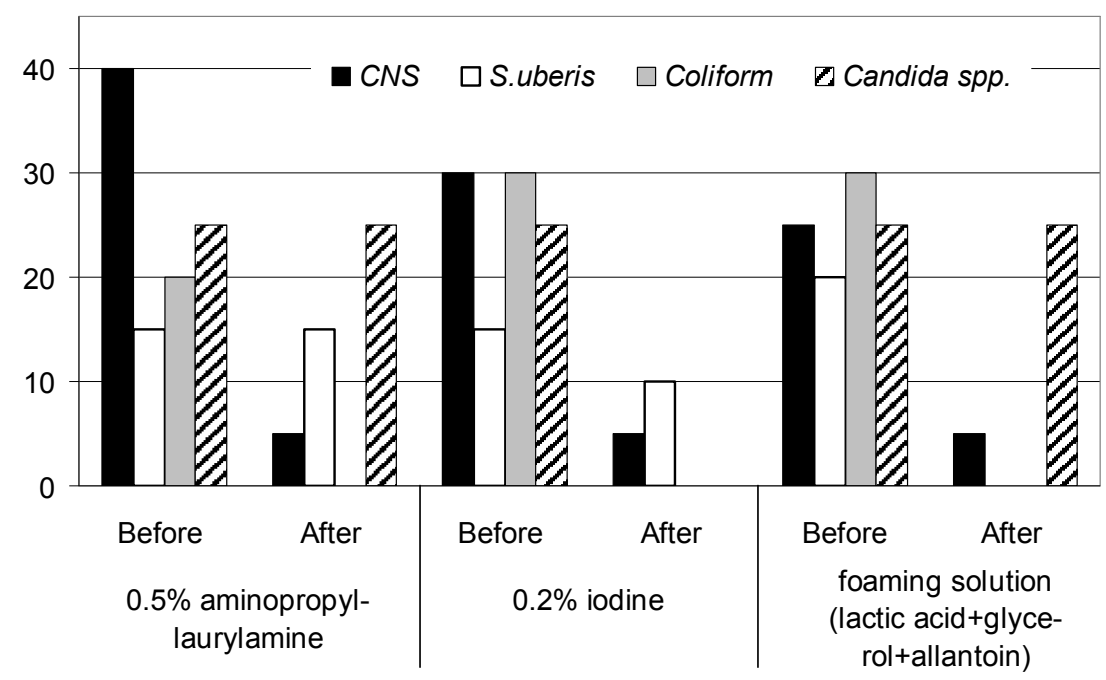

Fig. 2. Microbiological diversity before and after application of antiseptics.

$\mathrm{CNS}=$ coagulase-negative staphylococci

tamination on cows' teats skin decreased from $48.2 \pm 12.6 \times 10^{3} \quad \mathrm{CFU} / \mathrm{mL}$ to $\left.35.5 \pm 18.5 \times 10^{3} \mathrm{CFU} / \mathrm{mL}\right)$.

In our research, the treatment with $0.5 \%$ aminopropyl laurylamine resulted in a reduction of coagulase negative staphylococci by $35 \%$, of coliform by $20 \%-$ compared to $0.2 \%$ iodine and the foaming solution of natural compounds (lactic acid+glycerol+allantoin).

The treatment with $0.2 \%$ iodine resulted in a $25 \%$ reduction in Candida spp. (C. tropicalis $-30 \%$, Cr. laurentii $-20 \%$ ), after predipping with $0.5 \%$ laurylamine. The foaming solution of natural compounds (lactic acid+glycerol+allantoin) had no effect on Candida spp. In our study, no coliform bacteria were found after premilking applications (Fig. 2).

\section{DISCUSSION}

The effect of disinfection agents on hygienic milk quality and total bacterial con- tamination on cows teats has been evaluated in many studies (Galton et al., 1986; Galton et al., 1988; Nickerson, 2001; Ruegg, 2003). Other researchers (Kumar et al., 2012) also show that the use of some disinfectant products prior milking can have beneficial effects on reducing the levels of total bacterial, staphylococcal and streptococcal pathogens on teat skin. However, according to the results of some accomplished tests it can be stated that even thorough cleaning, wiping an udder does not significantly reduce contamination (Lam et al., 2000).

The findings of our study after using an antiseptic with iodine (the solution with $0.2 \%$ iodine decreased almost twice the number of microorganisms) is in accordance with the results of Blowey \& Collis (1992), who noticed that after application of iodine solution for teats germ-killing before milking, total bacterial contamination of the teats skin decreased by $70 \%$.

Japanese scientists (Mitsuo et al., 2003) have studied the efficacy of a non- 
iodine mixed fatty and lactic acid teat and disinfectant containing iodine. However, the teat skin condition of each cow was better after the non-iodine teat dip solution was applied. That also eliminates possible iodine contamination of the milk. The germicidal activity of lactic acid is moderate and thus is often combined with other germicides to improve the bactericidal effects. In our study the number of $\mathrm{CFU} / \mathrm{mL}$ on the teats skin significantly decreased when iodine and lactic acid solutions were used $(\mathrm{P}<0.05$ and $\mathrm{P}<0.01$, respectively).

Premilking using an antiseptic is most effective in the control of environmental pathogens (E. coli and environmental streptococci) and has been shown to have limited effectiveness against coagulase negative staphylococci (Ruegg \& Dohoo, 1997). Our test results are similar to other researchers' investigations. Pre-dipping has reduced new cases of mastitis caused by coliforms and environmental streptococci. According to Hemling (1998) antiseptic solutions containing iodine can reduce the quantity of staphylococci and other pathogens.

Antiseptics are not thought to be very effective against preventing new intramammary infections due to Candida spp. mastitis pathogens (Unnerstad et al., 2009). Costa et al. (2012) showed that the recommended $30 \mathrm{~s}$ period for the action of the pre-dipping solution to be effective was not observed, and milkers used a commercial solution based on iodine with a low concentration of the active ingredient in post-dipping.

Monsallier et al. (2012) showed that dairy cow characteristics could interact with farming practices. They offered prospects to better control teat microbial balance taking into account the milking hygiene practices, the parturition and the type of animal housing.

After using an antiseptic, coagulase negative staphylococci (CNS and Streptococcus uberis percentages were found to decrease. Oliver et al. (1993) conducted a predipping efficacy study using $0.25 \%$ iodine and found that new mastitis infections by Gram-negative bacteria were significantly lower in quarters with both predipped and postdipped teats versus quarters receiving only post dip.

\section{CONCLUSIONS}

According to our study, antiseptic solutions with active substance iodine and lactic acid proved to be effective and useful to reduce the bacterial populations on the cows' teat skin $(\mathrm{P}<0.05)$. The use of udder antiseptics for premilking teats preparation succeeded to reduce the levels of coagulase negative staphylococci and Streptococcus uberis but only $0.2 \%$ iodine could reduce Candida yests.

\section{REFERENCES}

Blowey, R. W \& K. Collis, 1992. Effect of premilking teat disinfection on mastitis incidence, total bacterial count, cell count and milk yield in three dairy herds. The Veterinary Record, 130, 175-178.

Costa, G. M., U. P. Pereira, Souza-Dias, M. A. G \& N. da Silva, 2012. Yeast mastitis outbreak in Brazilian dairy herd. Brazilian Journal of Veterinary Research and Animal Science, 49, 239-243.

El Behiry, A., G. Schlenker, I. Szabo \& U. J. Roesler, 2012. In vitro susceptibility of Staphylococcus aureus strains isolated from cows with subclinical mastitis to different antimicrobial agents. Journal of Veterinary Science, 13, 153-161.

Galton, D. M., L. G. Petersson \& W. G. Merrill, 1986. Effects of premilking udder 
preparation practices on bacterial counts in milk and on teats. Journal of Dairy Science, 69, 260-266.

Galton, D. M., L. G. Petersson \& W. G. Merrill, 1988. Evaluation of udder preparations on intramammary infections. Journal of Dairy Science, 71, 182-189.

Gibson, H., L. A. Sinclair, C. M. Brizuela, H. L. Worton \& R. G. Protheroe, 2008. Effectiveness of selected premilking teatcleaning regimes in reducing teat microbial load on commercial dairy farms. Letters in Applied Microbiology, 46, 295-300.

Gleeson, D., B. O'Brien, J. Flynn, E. O' Callaghan \& F. Galli, 2009. Effect of premilking teat preparation procedures on the microbial count on teats prior to cluster application. Irish Veterinary Journal, 62, 461-467.

Hemling, T. C., 1998. The effect of free iodine on the germicidal activity of iodine teat dips. Summary of peer-reviewed publications of efficacy of pre-milking and postmilking teat disinfectants. National Mastitis Council, 2011

Ingawa, K., H., R. W. Adkinson \& R. H. Gough, 1992. Evaluation of a gel teat cleaning and sanitizing compound for premilking hygiene. Journal of Dairy Science, 75, 1224-1232.

Kelly, P., T., K. O'Sullivan, D. P. Berry, S. J. More, W. J. Meaney, E. J. O'Callaghan \& B. O'Brien, 2009. Farm management factors associated with bulk tank total bacterial count in Irish dairy herds during 2006/2007. Irish Veterinary Journal, 62, $36-42$.

Kumar Vijaya, A., L. Venkateswara Rao,, M. Kishan Kumar, B. Srinu \& T. Madhava Rao, 2012. Efficacy of udder disinfectants on reduction of bacterial load and certain pathogens of public health significance. Journal of Microbiology and Biotechnology Research, 2, 147-151.

Lam, T. J., J. H. van Vliet \& Y. H. Schukken, 2000. Udder disinfection and mastitis in cattle: A literature review. Journal of Dairy Science, 8, 750-757.
Malinowski, E., 2004. The role of udder disinfection and sanitizer types. Medycyna Weterynaryjna, 56, 709-714.

Mitsuo, S., M. Takayuki \& Koichi, 2003. The efficacy of a non-iodine mixed fatty and lactic acid teat disinfectant solution on bovine udder health. Japanese Journal of Livestock Management, 38, 156-162.

Monsallier, F., I. Verdie-Metz, C. Agabriel, B. Martin \& M. C. Montel, 2012. Variability of microbial teat skin flora in relation to farming practices and individual dairy cow characteristics. Dairy Science and Technology, 92, 265-278.

Nakano, T., D. Sahara, T. Senou, M. Ichikawa, T. Ichikawa \& I Notsuki, 1995. The effects of different methods of premilking liner and teat preparation on bacterial counts in raw milk. In: Proceedings of the $3^{\text {rd }}$ International Mastitis Seminar, Part I, Tel Aviv, Israel, pp. 70-71.

Nickerson, S. C., 2001. Choosing the best teat dip for mastitis control and milk quality. In: Milk Quality Conference Proceedings, National Mastitis Council, Madison, USA, p. 43.

Oliver, S. P., M. J. Lewis, T. L. Ingle, B. E. Gillespie, K. R. Matthews \& H. H. Dowlen, 1993. Premilking teat disinfection for the prevention of environmental pathogen intramammary infections. Journal of Food Protection, 56, 852-855.

Pankey, J. W., Wildman, E. E., Drechsler, P. A \& N. S. Hogan, 1987. Field trial evaluation of premilking teat disinfection. Journal of Dairy Science, 70, 867-872.

Pavičic, Ž., T. Balenovic, M. Vučemilo, A. Tofant \& K. Matkovic, 2003. Application of disinfectant in the preparation of the udder for milking. In: Proceedings of Actual Questions of Animal Bioclimatology, Brno, Czech Republic, pp. 86-90.

Ruegg, P., L. \& I. R. Dohoo, 1997. A benefit to cost analysis of the effect of premilking teat hygiene on somatic cell count and intra-mammary infections in a com- 
Effect of pre-milking antiseptic treatment on the bacterial contamination of cow teats' skin

mercial dairy herd. Canadian Veterinary Journal, 38, 632-636.

Ruegg, P. L, 2003. Practical food safety interventions for dairy production. Journal of Dairy Science, 86 (E. Suppl.), E1-E9.

Taverna, M. A., L. F. Calvinho, M. Gaggiotti, G. A. Zimmermann,V. R. Canavesio, N. P. Aguirre \& R. Wanzerried, 2001. Effect of a premilking teat washing system on bacterial contamination of milk. In: National Mastitis Council Annual Meeting Proceedings, Madison, pp. 201-203

Tortora, G. J., B. R. Funke, C. L. Case \& B. Cummings, 2002. Microbiology: An Introduction. $7^{\text {th }}$ edn.

Unnerstad, H. E., A. Lindberg, K. P. Waller, T. Ekman, K. Artursson, M. Nilsson-Ost and B. \& Bengtsson, 2009. Microbial aetiology of acute clinical mastitis and agentspecific risk factors. Veterinary Microbiology, 137, 90-97.
Vacheyrou, M., A. C. Normand, P. Guyot, C. Cassagne, R. Piarroux \& Y. Bouton, 2011. Cultivable microbial communities in raw cow milk and potential transfers from stables of sixteen French farms. International Journal of Food Microbiology, 146, 253 262.

Paper received 05.06.2014; accepted for publication 02.10 .2014

\section{Correspondence:}

Ramute Miseikiene

Veterinary Academy,

Lithuanian University of Health Sciences

18 , Tilžès Street

LT-47181 Kaunas, Lithuania

e-mail: ramute.miseikiene@lva.lt 